\title{
Report
}

\section{SARS-CoV-2 infections elicit higher levels of original antigenic sin antibodies compared to SARS-CoV-2 mRNA vaccinations}

Elizabeth M. Anderson ${ }^{1}$, Theresa Eilola ${ }^{1}$, Eileen Goodwin ${ }^{1}$, Marcus J. Bolton ${ }^{1}$, Sigrid Gouma ${ }^{1}$, Rishi R. Goel ${ }^{2,3,4}$, Mark M. Painter ${ }^{2,3,4}$, Sokratis A. Apostolidis ${ }^{2,3,5}$, Divij Mathew ${ }^{2,3,4}$, Debora Dunbar $^{6}$, Danielle Fiore 7 , Amanda Brock ${ }^{8}$, JoEllen Weaver ${ }^{8}$, John S. Millar ${ }^{9}$, Stephanie DerOhannessian $^{8,9}$, The UPenn COVID Processing Unit ${ }^{10}$, Allison R. Greenplate ${ }^{2,3}$, Ian Frank ${ }^{6}$, Daniel J. Rader ${ }^{8,9}$, E. John Wherry ${ }^{2,3,4,11}$, Scott E. Hensley ${ }^{1,2^{*}}$

${ }^{1}$ Department of Microbiology, Perelman School of Medicine, University of Pennsylvania, Philadelphia, PA 19104, USA

${ }^{2}$ Institute for Immunology, Perelman School of Medicine, University of Pennsylvania, Philadelphia, PA 19104, USA

${ }^{3}$ Immune Health, Perelman School of Medicine, University of Pennsylvania, Philadelphia, PA 19104, USA

${ }^{4}$ Department of Systems Pharmacology and Translational Therapeutics, University of Pennsylvania, Philadelphia, PA 19104, USA

${ }^{5}$ Division of Rheumatology, Perelman School of Medicine, University of Pennsylvania, Philadelphia, PA 19104, USA

${ }^{6}$ Division of Infectious Diseases, Perelman School of Medicine, University of Pennsylvania, Philadelphia, PA 19104, USA

${ }^{7}$ Department of Psychiatry, Perelman School of Medicine, University of Pennsylvania, Philadelphia, PA 19104, USA

${ }^{8}$ Institute for Translational Medicine and Therapeutics, Perelman School of Medicine, University of Pennsylvania, Philadelphia, PA 19104, USA

${ }^{9}$ Department of Genetics and Medicine, Perelman School of Medicine, University of Pennsylvania, Philadelphia, PA 19104, USA

${ }^{10}$ The UPenn COVID Processing Unit is a unit of individuals from diverse laboratories at the University of Pennsylvania who volunteered time and effort to enable study of COVID-19 patients during the pandemic. Members are listed in the acknowledgement section.

${ }^{11}$ Parker Institute for Cancer Immunotherapy, Perelman School of Medicine, University of Pennsylvania, PA 19104, USA

*Correspondence: hensley@pennmedicine.upenn.edu 


\section{Infected}

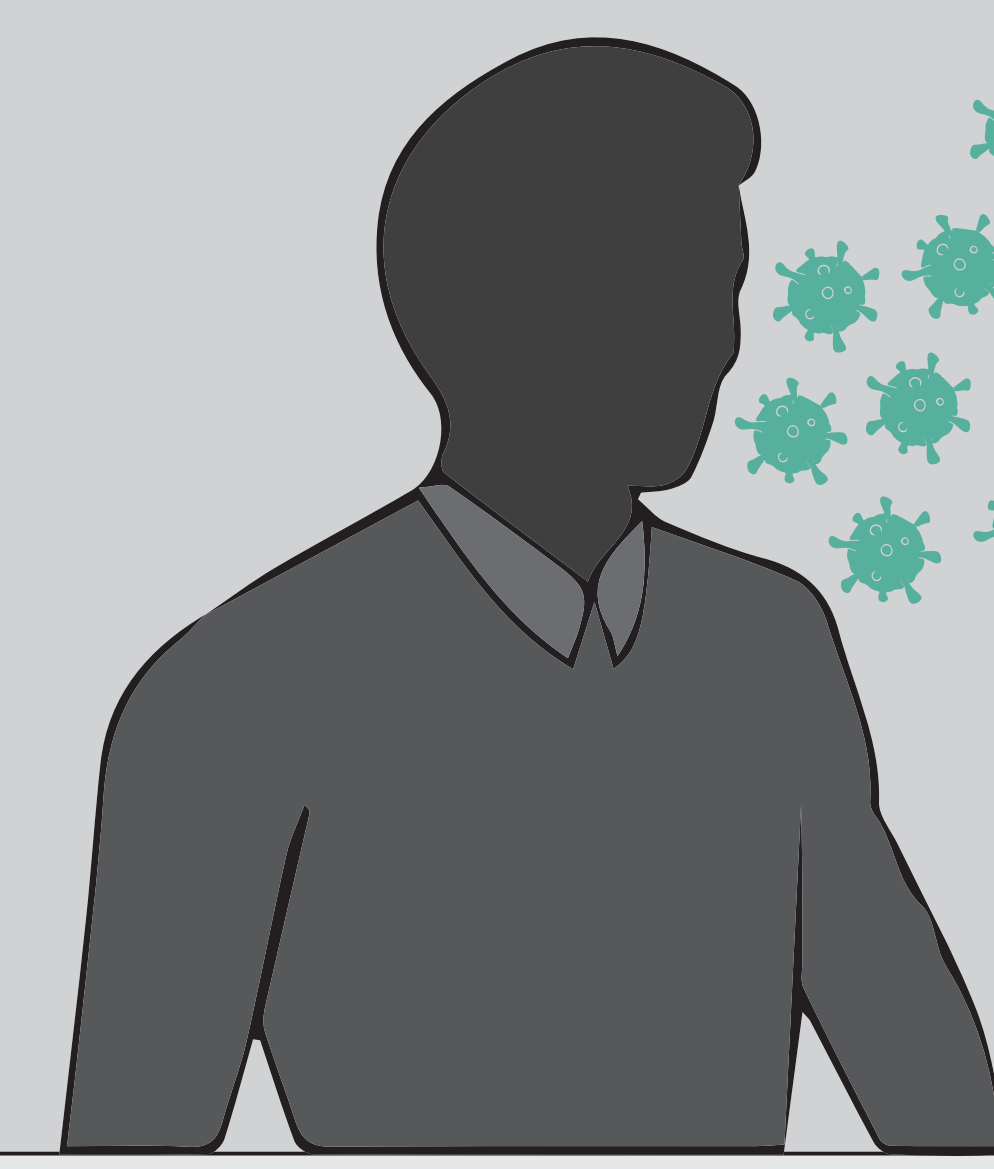

\section{Vaccinated}

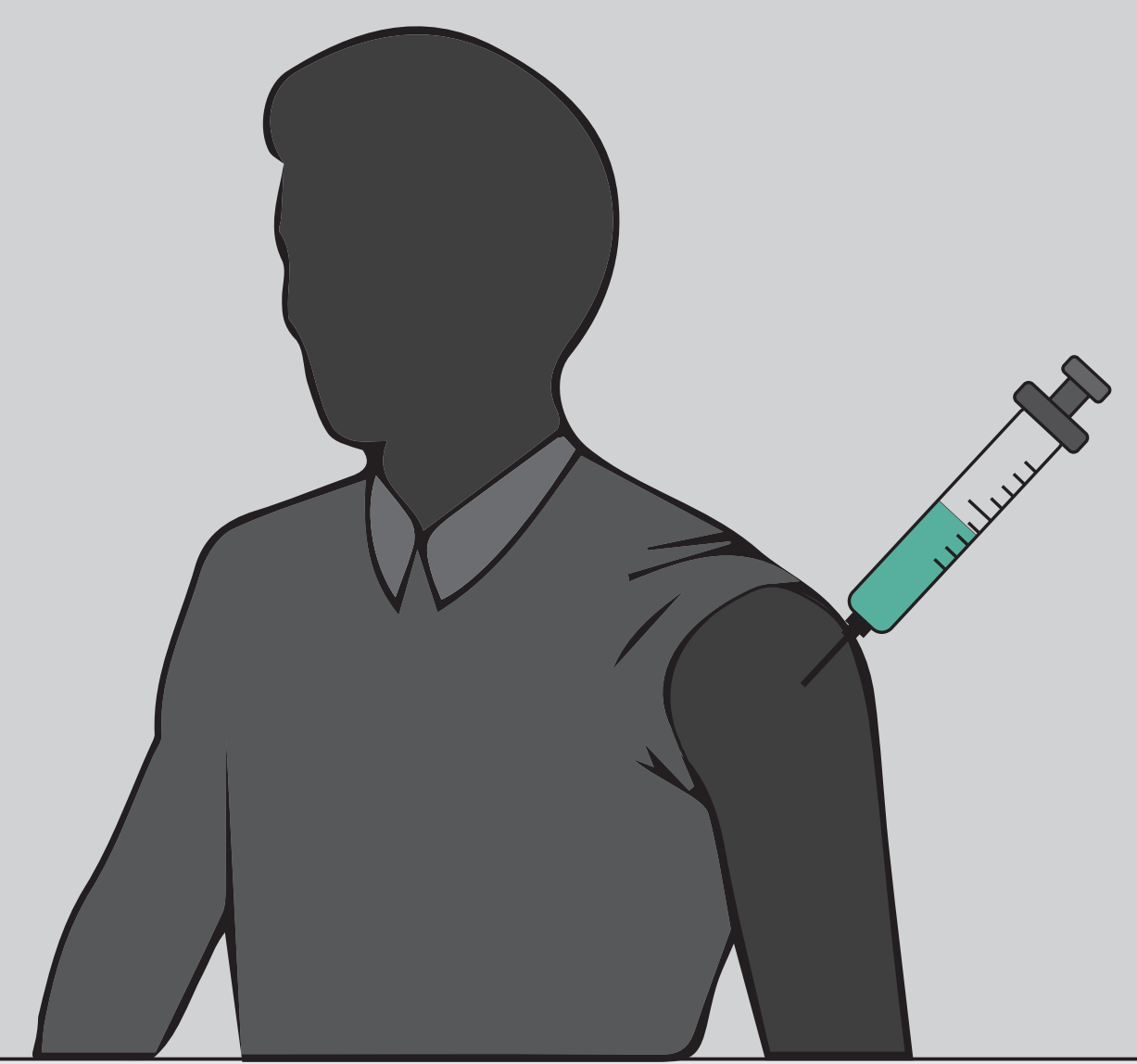

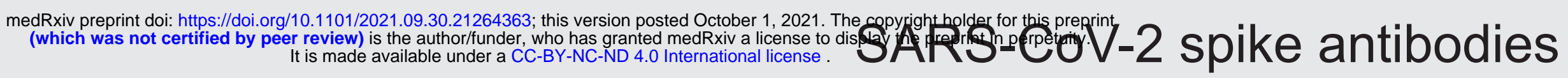

Subunit

$\square$ S1

$\square$ S2

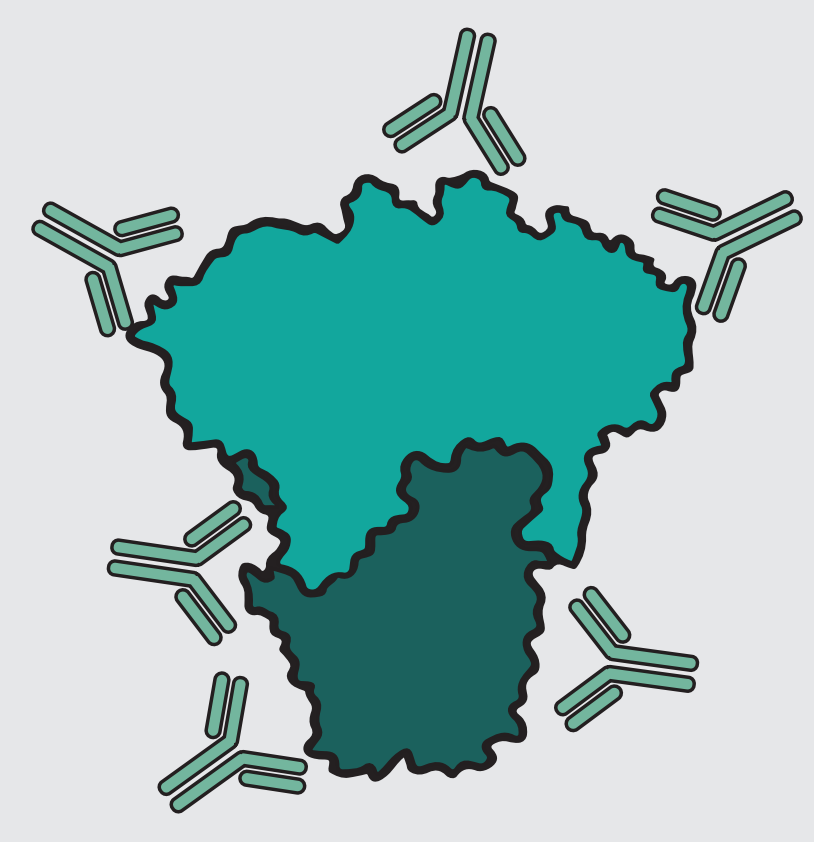

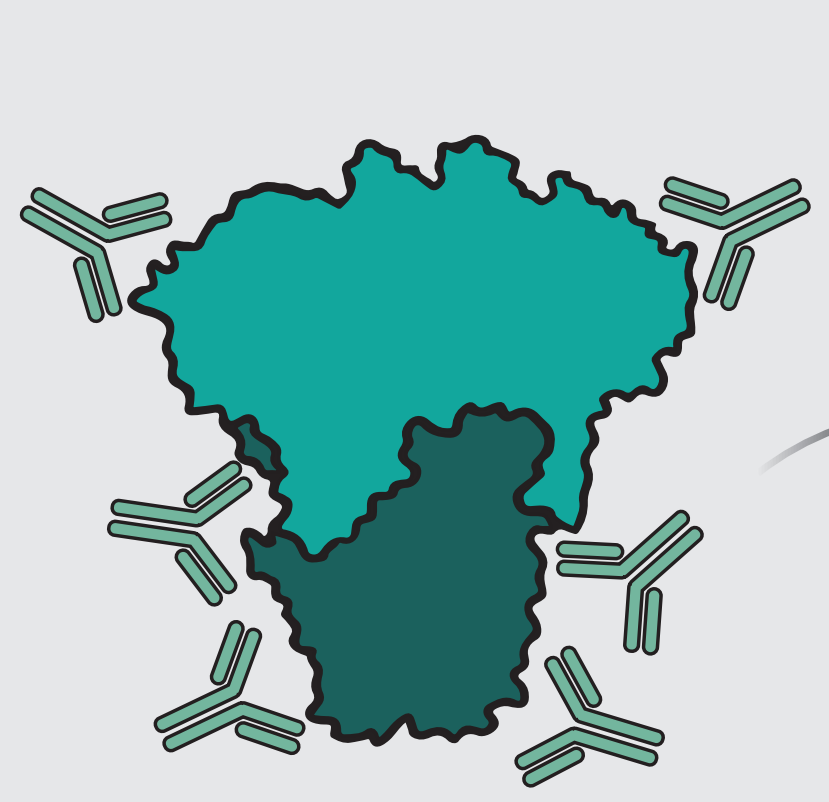

1st dose

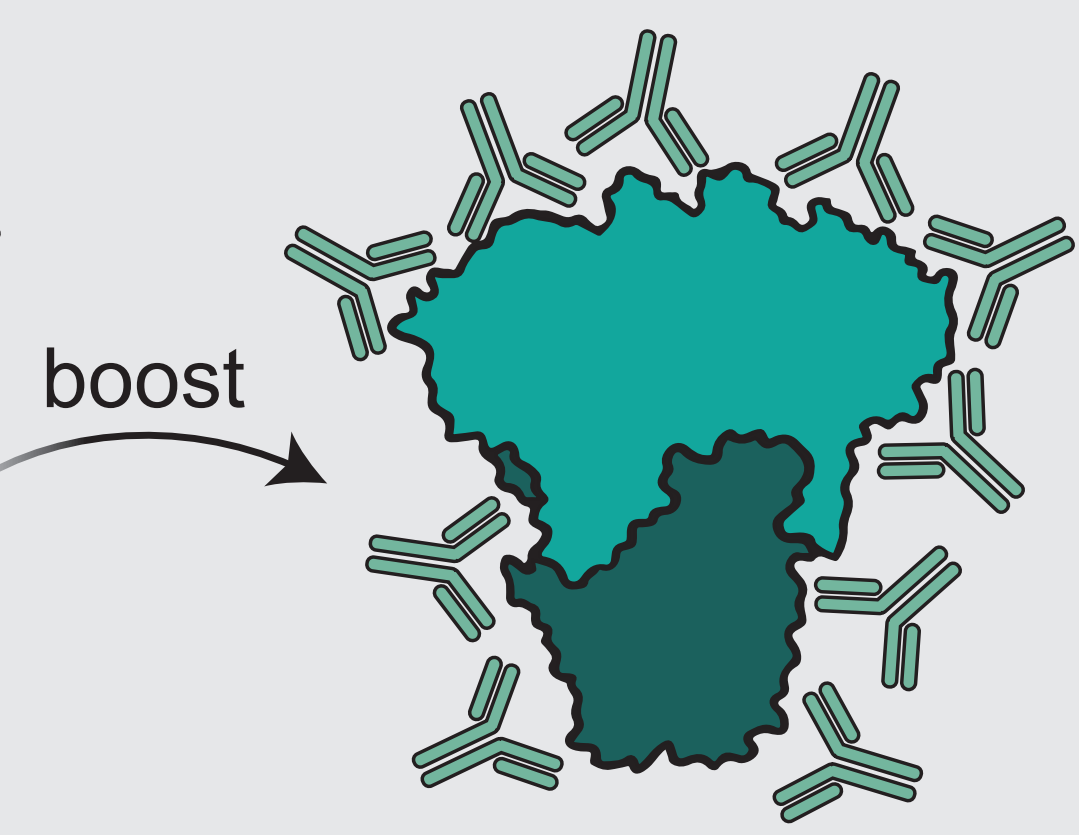

2nd dose

Back boosting of $\beta$-hCoV antibodies
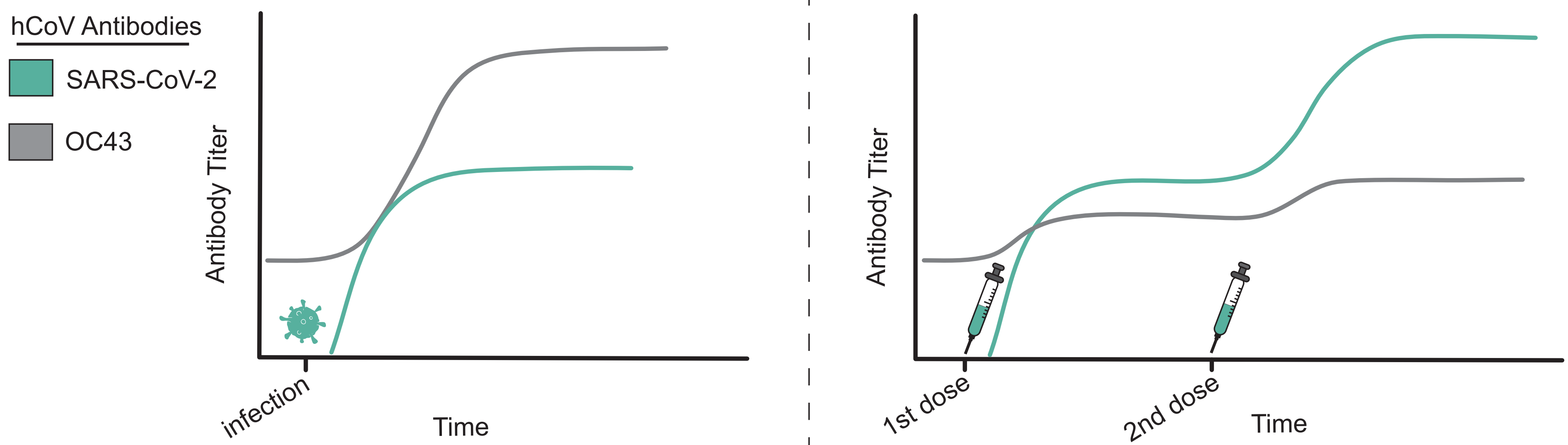
medRxiv preprint doi: https://doi.org/10.1101/2021.09.30.21264363; this version posted October 1, 2021. The copyright holder for this preprint (which was not certified by peer review) is the author/funder, who has granted medRxiv a license to display the preprint in perpetuity. It is made available under a CC-BY-NC-ND 4.0 International license.

\section{HIGHLIGHTS}

- SARS-CoV-2 mRNA vaccines elicit higher levels of antibodies compared to SARS-CoV2 infections

- The first dose of an mRNA vaccine generates both S1 and S2 responses while the second dose boosts primarily $\mathrm{S} 1$-specific antibodies

- SARS-CoV-2 infections, but not mRNA vaccinations, elicit high levels of antibodies that 
medRxiv preprint doi: https://doi.org/10.1101/2021.09.30.21264363; this version posted October 1, 2021. The copyright holder for this preprint (which was not certified by peer review) is the author/funder, who has granted medRxiv a license to display the preprint in perpetuity.

It is made available under a CC-BY-NC-ND 4.0 International license .

\section{SUMMARY}

10 Severe acute respiratory syndrome coronavirus 2 (SARS-CoV-2) mRNA vaccines elicit higher

11 levels of antibodies compared to natural SARS-CoV-2 infections in most individuals; however,

12 the specificities of antibodies elicited by vaccination versus infection remain incompletely

13 understood. Here, we characterized the magnitude and specificity of SARS-CoV-2 spike-reactive

14 antibodies from 10 acutely infected health care workers and 23 participants who received

15 mRNA-based SARS-CoV-2 vaccines. We found that infection and primary mRNA vaccination

16 elicited S1 and S2-reactive antibodies, while secondary vaccination boosted mostly S1

17 antibodies. Using magnetic bead-based absorption assays, we found that SARS-CoV-2 infections

18 elicited a large proportion of original antigenic sin-like antibodies that bound efficiently to

19 common seasonal human coronaviruses but poorly to SARS-CoV-2. In converse, vaccination

20 only modestly boosted antibodies reactive to common seasonal human coronaviruses and these

21 antibodies bound efficiently to SARS-CoV-2. Our data indicate that SARS-CoV-2 mRNA

22 vaccinations elicit fundamentally different antibody responses compared to SARS-CoV-2

23 infections.

\section{KEYWORDS}

25 SARS-CoV-2, antibodies, mRNA vaccines, original antigenic sin, coronavirus 
medRxiv preprint doi: https://doi.org/10.1101/2021.09.30.21264363; this version posted October 1, 2021. The copyright holder for this preprint (which was not certified by peer review) is the author/funder, who has granted medRxiv a license to display the preprint in perpetuity. It is made available under a CC-BY-NC-ND 4.0 International license .

\section{BACKGROUND}

Since late 2019 severe acute respiratory syndrome coronavirus 2 (SARS-CoV-2) has spread across the world causing a global pandemic ${ }^{1,2}$. This prompted the rapid development of several SARS-CoV-2 vaccines including two that use an mRNA-based platform (reviewed in ${ }^{3-5}$ ). The mRNA vaccines, Pfizer BNT162b2 and Moderna mRNA-1273, employ lipid nanoparticles that encase modified mRNA encoding the spike protein of SARS-CoV-2 ${ }^{6}$. SARS-CoV-2 mRNA vaccines have been found to be safe and effective at preventing severe COVID-19, hospitalizations, and death ${ }^{7,8}$. Recent studies demonstrate that SARS-CoV-2 mRNA vaccines elicit long-lived antibody responses that partially recognize and protect against antigenically distinct SARS-CoV-2 variants ${ }^{9-15}$.

Some studies suggest that prior infections with common seasonal human coronaviruses (hCoVs) impact the severity of SARS-CoV-2 infections ${ }^{16,17}$. Most individuals are exposed to hCoVs early in childhood ${ }^{18-23}$ and then re-exposed to antigenically drifted forms of these viruses throughout life ${ }^{24-26}$. Common hCoVs include the HKU1 and OC43 betacoronaviruses ( $\beta$-hCoVs) and 229E and NL63 alphacoronaviruses ${ }^{27-30}$. Studies from our group and others have shown that some individuals possessed antibodies that could bind to SARS-CoV-2 proteins prior to the COVID-19 pandemic ${ }^{18,31,32}$. SARS-CoV-2 is a $\beta-\mathrm{hCoV}$, and antibodies reactive to the OC43 $\beta$ hCoV can be boosted upon SARS-CoV-2 infections ${ }^{16,18,32,33}$ and SARS-CoV-2 mRNA vaccinations $^{34-36}$. It is unknown if the recall of $\beta-\mathrm{hCoV}$ antibodies upon SARS-CoV-2 infections impacts disease outcome. A recent study suggests that the recall of OC43 $\beta$-hCoV antibodies is associated with a compromised de novo SARS-CoV-2 response in individuals with fatal COVID$19^{37}$.

The boosting of hCoV antibodies upon infection with the antigenically distinct SARS$\mathrm{CoV}-2$ is consistent with the doctrine of 'original antigenic sin', first proposed to describe influenza virus antibody responses by Thomas Francis in $1960^{38}$. We recently developed new absorption assays to show that sequential heterosubtypic influenza virus infections elicit antibodies

54 that paradoxically do not bind effectively to the boosting viral strain ${ }^{39}$. In the current report, we

55 used a similar absorption technique to define the specificity of $\beta-\mathrm{hCoV}$ antibodies elicited by 56 SARS-CoV-2 infections. We completed a series of studies to determine if these boosted $\beta$-hCoV 57 antibodies could cross-react to SARS-CoV-2 and we compared antibodies elicited by SARS-CoV582 infections and SARS-CoV-2 mRNA vaccinations. 
medRxiv preprint doi: https://doi.org/10.1101/2021.09.30.21264363; this version posted October 1, 2021. The copyright holder for this preprint (which was not certified by peer review) is the author/funder, who has granted medRxiv a license to display the preprint in perpetuity.

It is made available under a CC-BY-NC-ND 4.0 International license.

\section{RESULTS}

SARS-CoV-2 infections and vaccinations elicit antibodies against the SARS-CoV-2 spike protein

We obtained samples from individuals before and after acute SARS-CoV-2 infections $(\mathrm{n}=10)$ and pre-/post- two doses of a Pfizer BNT162b2 mRNA SARS-CoV-2 vaccine $(\mathrm{n}=23)$.

63 Samples from SARS-CoV-2 infected individuals were obtained from a health care worker sero-

64 monitoring study in which all infections were relatively mild ${ }^{16}$. All 10 individuals were 65 seronegative in the beginning of this study and acquired a PCR-confirmed SARS-CoV-2 infection 66 over the course of the study. Blood samples were collected from SARS-CoV-2 infected individuals 67 5-28 days (mean 17.9 days) after PCR-confirmed infections. Blood samples were collected from SARS-CoV-2 mRNA vaccinated individuals ${ }^{40} 7-15$ days post-primary immunization (mean 14.2 days), the day of or day before the booster immunization (mean 21.2 days post-primary), and 7-12 days post-booster immunization (mean 7.5 days post-boost). Individuals in our infection and vaccination studies had similar ages and both groups were predominantly female (Supplemental Table 1).

Consistent with previous studies (reviewed $\mathrm{in}^{41}$ ), antibodies against the full-length spike (FL-S) of SARS-CoV-2 increased following infection (Figure 1A) and vaccination (Figure 1B). SARS-CoV-2 FL-S antibody levels were similar following infections and primary vaccinations, and antibody levels were significantly boosted following the second dose of vaccine (Figure 1BC). The SARS-CoV-2 FL-S protein consists of two domains, the S1 domain which encompasses the receptor binding domain (RBD) essential for cell attachment and entry ${ }^{42-45}$ and the $\mathrm{N}$ terminal domain (NTD), and the S2 domain which shares more sequence homology with $\mathrm{hCoVs}^{28,33}$. Infection and primary vaccination elicited high levels of both S1 and S2 antibodies (Figure 1AB), whereas secondary vaccinations boosted S1 antibodies more efficiently compared to S2 antibodies (Figure 1B, D-E).

$\underline{\text { SARS-CoV-2 infections and vaccinations elicit antibodies against a common human }}$ betacoronavirus

We previously found that antibodies against the FL-S of the OC43 $\beta-\mathrm{hCoV}$ are boosted

88 findings, we found that antibodies reactive to the OC43 FL-S increased upon SARS-CoV-2

89 infections in health care workers with mild disease (Figure 2A). A recent study showed that 
medRxiv preprint doi: https://doi.org/10.1101/2021.09.30.21264363; this version posted October 1, 2021. The copyright holder for this preprint (which was not certified by peer review) is the author/funder, who has granted medRxiv a license to display the preprint in perpetuity.

It is made available under a CC-BY-NC-ND 4.0 International license .

antibody titers against $\beta$-hCoVs increase upon SARS-CoV-2 mRNA vaccination ${ }^{36}$. Although we found small increases in OC43 FL-S antibody titers following SARS-CoV-2 mRNA vaccinations (Figure 2B), the magnitude of OC43 FL-S antibody boosts were much lower following vaccinations compared to infections for most individuals (Figure 2C). Antibodies boosted by infections and vaccinations primarily targeted the S2 domain of the OC43 spike (Figure 2A-B, 2D-E), with infections boosting S2 responses more effectively compared to vaccinations (Figure 2E). Booster vaccinations did not affect levels of OC43 FL-S, S1, or S2 antibody levels (Figure 2B-E).

\section{SARS-CoV-2 infections elicit higher levels of original antigenic sin antibodies compared to SARS-}

\section{CoV-2 mRNA vaccinations}

We previously developed absorption-based assays to measure the level of cross-reactivity of antibodies elicited by influenza virus infections ${ }^{39}$. In that study, we sequentially infected ferrets with two antigenically distinct influenza virus strains and analyzed serum samples collected after each infection. We found that many antibodies elicited by secondary influenza virus infections paradoxically did not bind effectively to the secondary boosting influenza virus strain. We proposed that antigenically distinct influenza viruses engage memory B cells elicited by prior infections through multiple low affinity interactions with thousands of B cell receptors on memory B cells. Low affinity antibodies secreted in a soluble form through this recall response fail to bind to the antigenically distinct recall antigens because they require the level of multivalent binding that is provided on B cells.

We developed a magnetic bead-based absorption assay to determine if OC43 FL-S antibodies elicited by SARS-CoV-2 infection and vaccination cross-react with SARS-CoV-2 FLS. We incubated serum samples with beads coupled with either OC43 FL-S or SARS-CoV-2 FL$\mathrm{S}$ and then we depleted bead-reactive antibodies using a magnetic column. Then, we quantified antibody levels in serum absorbed with antigen coupled beads to assess antibody cross-reactivity. SARS-CoV-2 FL-S-reactive antibodies elicited by infection were efficiently depleted with SARSCoV-2 FL-S coupled beads but not OC43 FL-S coupled beads (Figure 3A). OC43 FL-S-reactive antibodies boosted by SARS-CoV-2 infection were efficiently depleted with OC43 FL-S coupled beads, but surprisingly these antibodies were not depleted with SARS-CoV-2 FL-S coupled beads (Figure 3B). These results are surprising since these OC43 FL-S-reactive antibodies were boosted 
medRxiv preprint doi: https://doi.org/10.1101/2021.09.30.21264363; this version posted October 1, 2021. The copyright holder for this preprint (which was not certified by peer review) is the author/funder, who has granted medRxiv a license to display the preprint in perpetuity.

It is made available under a CC-BY-NC-ND 4.0 International license .

121 upon SARS-CoV-2 infection. Vaccination-elicited antibodies had different cross-reactive 122 properties compared to infection-elicited antibodies. Similar to antibodies elicited by infection, 123 SARS-CoV-2 FL-S-reactive antibodies elicited by vaccination were efficiently depleted with 124 SARS-CoV-2 FL-S coupled beads but not OC43 FL-S coupled beads (Figure 3D). In contrast to 125 antibodies elicited by infection, OC43 FL-S-reactive antibodies boosted by SARS-CoV-2 126 vaccination were efficiently depleted with both OC43 FL-S and SARS-CoV-2 FL-S coupled beads

127 (Figure 3B). As a control, we quantified levels of influenza virus hemagglutinin (HA) antibodies 128 in these experiments and we found that HA-reactive antibodies were not depleted with SARS129 CoV-2 FL-S or OC43 FL-S labeled beads (Figure 3C, 3F). Taken together, our data suggest that 130 SARS-CoV-2 infection elicits OC43 FL-S-reactive antibodies that bind poorly to SARS-CoV-2 131 FL-S, while SARS-CoV-2 mRNA vaccinations elicits a relatively lower level of OC43 FL-S132 reactive antibodies that efficiently cross-react with both OC43 FL-S and SARS-CoV-2 FL-S.

\section{DISCUSSION}

135 Here we found that polyclonal antibodies elicited by SARS-CoV-2 mRNA vaccines are at 136 a higher magnitude and have different specificities compared to those elicited by SARS-CoV-2 137 infections. We demonstrate that primary vaccinations elicit antibodies that bind to the S1 and S2 138 region of SARS-CoV-2 spike, and that S1-specific antibody responses are preferentially boosted 139 after second vaccine doses. These data are consistent with recent reports that indicate that mRNA 140 vaccinations elicit broader and more diverse antibody responses that are more effective at neutralizing SARS-CoV-2 variants compared to antibodies elicited by infection ${ }^{15,46-48} 49$.

142 We found major differences in OC43 spike binding between antibodies elicited by SARS-

143 CoV-2 infections versus mRNA vaccinations. SARS-CoV-2 infections elicited high levels of 144 antibodies that bound to the S2 region of the OC43 spike protein; however, our absorption assays 145 demonstrated that these antibodies bound poorly to the SARS-CoV-2 spike. Conversely, we found 146 that SARS-CoV-2 mRNA vaccinations elicited lower levels of antibodies that reacted to the S2 147 region of the OC43 spike protein. Unlike antibodies elicited by infections, these vaccine-elicited 148 antibodies were truly cross-reactive and bound efficiently to both SARS-CoV-2 and OC43 spike 149 proteins. Further studies will be required to fully understand mechanisms that lead to different 150 types of antibody responses elicited by SARS-CoV-2 infections versus vaccinations. It is possible 151 that memory $\mathrm{B}$ cells elicited by prior $\beta-\mathrm{hCoV}$ infections are recalled by both SARS-CoV-2 
medRxiv preprint doi: https://doi.org/10.1101/2021.09.30.21264363; this version posted October 1, 2021. The copyright holder for this preprint (which was not certified by peer review) is the author/funder, who has granted medRxiv a license to display the preprint in perpetuity.

It is made available under a CC-BY-NC-ND 4.0 International license .

152 infections and vaccinations, and that long-lived germinal centers elicited by mRNA vaccinations ${ }^{50}$

153 are required to allow for somatic hypermutations that promote the formation of cross-reactive S2

154 antibodies that bind efficiently to the spike proteins of both $\beta$-hCoVs and SARS-CoV-2.

155 Consistent with this, a recent study found that S2-specific B cells with a memory phenotype are

156 quickly recruited following primary immunization of humans ${ }^{51}$

157 Boosting of OC43 S2-reactive antibodies following SARS-CoV-2 infection is consistent

158 with Thomas Francis' doctrine of 'original antigenic sin' ${ }^{38}$. Francis found that antibodies elicited

159 by influenza vaccines often bound strongly to influenza virus strains that an individual was

160 exposed to in childhood, although it is not apparent if these recalled influenza virus antibody

161 responses typically occur at the expense of producing de novo antibodies (as we reviewed here ${ }^{52}$ )

162 The functional consequences of recalling low affinity S2-reactive antibodies following SARS-

163 CoV-2 infections are unclear. Our previous studies found no correlation between OC43-reactive

164 antibody induction and disease outcome following SARS-CoV-2 infection ${ }^{18}$ but a recent study

165 suggested that the recall of OC43-reactive antibodies is associated with a compromised de novo

166 SARS-CoV-2 response in individuals with fatal COVID-1937. Further studies are required to

167 determine how the induction of different types of hCoV and SARS-CoV-2 antibodies affect

168 disease outcome following SARS-CoV-2 infections.

169

170

171 
medRxiv preprint doi: https://doi.org/10.1101/2021.09.30.21264363; this version posted October 1, 2021. The copyright holder for this preprint (which was not certified by peer review) is the author/funder, who has granted medRxiv a license to display the preprint in perpetuity.

It is made available under a CC-BY-NC-ND 4.0 International license .

\section{STAR METHODS}

\section{KEY RESOURCES TABLE}

\begin{tabular}{|c|c|c|}
\hline REAGENT or RESOURCE & SOURCE & IDENTIFIER \\
\hline \multicolumn{3}{|l|}{ Antibodies } \\
\hline Goat anti-human IgG-HRP & Jackson ImmunoResearch & $109-036-098$ \\
\hline mAb CR3022 & Produced for this paper & $\mathrm{N} / \mathrm{A}$ \\
\hline mAb CR9114 & Produced for this paper & N/A \\
\hline \multicolumn{3}{|l|}{ Biological Samples } \\
\hline $\begin{array}{l}\text { Acutely SARS-CoV-2 infected HCW } \\
\text { serum samples }\end{array}$ & The University of Pennsylvania & Gouma et al., 2021 \\
\hline $\begin{array}{l}\text { SARS-CoV-2 mRNA vaccinated } \\
\text { participants serum samples }\end{array}$ & The University of Pennsylvania & Goel et al., 2021 \\
\hline \multicolumn{3}{|c|}{ Chemicals, Peptides, and Recombinant Proteins } \\
\hline SARS-CoV-2 spike protein & Produced for this paper & $\bar{N} / \mathrm{A}$ \\
\hline SARS-CoV-2 S1 subunit protein & ACROBiosystems & Cat. S1N-C52H3 \\
\hline SARS-CoV-2 S2 subunit protein & ACROBiosystems & Cat. S2N-C52H5 \\
\hline OC43 spike protein & Sino Biological & Cat. 40607-V08B \\
\hline OC43 S1 subunit protein & Produced for this paper & $\mathrm{N} / \mathrm{A}$ \\
\hline OC43 S2 subunit protein & Produced for this paper & $\mathrm{N} / \mathrm{A}$ \\
\hline IVR-190 H1N1 rHA & Produced for this paper & $\mathrm{N} / \mathrm{A}$ \\
\hline \multicolumn{3}{|l|}{ Experimental Models: Cell Lines } \\
\hline $293 T$ & ATCC & $\begin{array}{l}\text { Cat. CRL-3216, } \\
\text { RRID:CVCL } 0063\end{array}$ \\
\hline $293 \mathrm{~F}$ & $\begin{array}{l}\text { Laboratory of Scott Hensley, } \\
\text { University of Pennsylvania, PA }\end{array}$ & $\begin{array}{l}\text { Thermo Fisher cat. } \\
\text { R79007 }\end{array}$ \\
\hline \multicolumn{3}{|l|}{ Recombinant DNA } \\
\hline Plasmid: pCAGGS SARS-CoV-2 spike & $\begin{array}{l}\text { Laboratory of Florian Krammer, } \\
\text { Mt. Sinai, NY }\end{array}$ & Amanat et al., 2020 \\
\hline Plasmid: OC43 rS1 & $\begin{array}{l}\text { Laboratory of Scott Hensley, } \\
\text { University of Pennsylvania, PA }\end{array}$ & Anderson et al., 2021 \\
\hline Plasmid: OC43 rS2 & $\begin{array}{l}\text { Laboratory of Scott Hensley, } \\
\text { University of Pennsylvania, PA }\end{array}$ & Anderson et al. 2021 \\
\hline Plasmid: mAb CR3022 HC & $\begin{array}{l}\text { Laboratory of Ian Wilson, } \\
\text { Scripps Research Institute, CA }\end{array}$ & Yaun et al., 2020 \\
\hline Plasmid: mAb CR3022 LC & $\begin{array}{l}\text { Laboratory of lan Wilson, } \\
\text { Scripps Research Institute, CA }\end{array}$ & Yaun et al., 2020 \\
\hline Plasmid: mAb CR9114 HC & $\begin{array}{l}\text { Laboratory of lan Wilson, } \\
\text { Scripps Research Institute, CA }\end{array}$ & Dreyfus et al., 2012 \\
\hline Plasmid: mAb CR9114 LC & $\begin{array}{l}\text { Laboratory of lan Wilson, } \\
\text { Scripps Research Institute, CA }\end{array}$ & Dreyfus et al., 2012 \\
\hline \multicolumn{3}{|l|}{ Software and Algorithms } \\
\hline Prism8 & GraphPad Software & $\begin{array}{l}\text { www.graphpad.com/scienti } \\
\text { fic-software/prism/ }\end{array}$ \\
\hline
\end{tabular}


medRxiv preprint doi: https://doi.org/10.1101/2021.09.30.21264363; this version posted October 1, 2021. The copyright holder for this preprint (which was not certified by peer review) is the author/funder, who has granted medRxiv a license to display the preprint in perpetuity.

It is made available under a CC-BY-NC-ND 4.0 International license .

\section{RESOURCES AVAILABILITY}

\section{Lead Contact}

Further information and requests for resources and reagents should be directed to and will be fulfilled by the Lead Contact, Scott E. Hensley (hensley@pennmedicine.upenn.edu).

\section{Materials Availability}

All unique reagents generated in this study will be available from the Lead Contact upon reasonable request.

\section{Data and Code Availability}

All raw data generated in this study will be deposited on Mendeley Data:

\section{EXPERIMENTAL MODEL AND SUBJECT DETAILS}

\section{Samples from Human Subjects}

The infection cohort described in this report consists of health care workers within the University of Pennsylvania Healthcare System who were recruited into a SARS-CoV-2 seromonitoring study that included biweekly blood draws as previously described ${ }^{16}$. A nasal pharyngeal (NP) swab was collected from all health care workers who tested positive for SARSCoV-2 IgG and or IgM antibodies or who were experiencing COVID-like symptoms during the study period. NP swabs were PCR tested for the presence of SARS-CoV-2 viral RNA. Seroconverted health care workers with PCR-confirmed SARS-CoV-2 infection ( $\mathrm{n}=10$ adults $\geq 18$ years old) were included in this analysis.

The vaccination cohort described in this report consists of participants ( $n=23$ adults $\geq 18$ years old) who enrolled in a study at the University of Pennsylvania that included blood draws before and after two vaccination doses with an mRNA-based COVID-19 vaccine as previously described $^{40}$. Whole blood was collected from participants who provided proof of vaccination with Pfizer (BNT162b2) mRNA vaccines. Samples were collected at 4 timepoints: 1-2 weeks before vaccination (baseline) (visit 1; V1), 1-2 weeks post-primary immunization (visit 2; V2), the day of or day before booster immunization (visit 3; V3), and 1-2 weeks post-booster immunization 
medRxiv preprint doi: https://doi.org/10.1101/2021.09.30.21264363; this version posted October 1, 2021. The copyright holder for this preprint (which was not certified by peer review) is the author/funder, who has granted medRxiv a license to display the preprint in perpetuity.

It is made available under a CC-BY-NC-ND 4.0 International license .

(visit 4; V4). Only participants without prior SARS-CoV-2 exposure were included in this report. Plasma and PBMCs were isolated from whole blood for downstream assays.

All sera and plasma samples were heat-inactivated in a $56^{\circ} \mathrm{C}$ water bath for 1 hour prior to serological testing. All samples were collected after obtaining informed consent and studies were approved by the University of Pennsylvania Institutional Review Board.

\section{Cell lines}

293F cells were from Thermo fisher (Thermo Fisher cat. R79007). 293T cells were from

215 ATCC (ATCC cat. CRL-3216, RRID:CVCL_0063). All cell lines were cultured using 216 manufacturer's guidelines and used as described in Method Details below.

\section{METHOD DETAILS}

\section{Proteins for serological studies}

SARS-CoV-2 full length spike (FL-S) protein was purified by Ni-NTA resin from 293F cells transfected with a plasmid that encodes the FL-S (A gift from Florian Krammer, Icahn School of Medicine at Mt. Sinai, New York City NY) ${ }^{53}$. S1 and S2 subunits of the SARS-CoV-2 spike were purchased from Acro Biosystems (ACROBiosystems, Newark, DE; cat. S1N-C52H3, and S2N-C52H5, respectively) and reconstituted in $200 \mu \mathrm{L}$ Dulbecco's phosphate buffered saline (DPBS) to a final concentration of $500 \mu \mathrm{g} / \mathrm{mL}$. OC43 FL-S was also purchased (Sino Biological,

226 Wayne PA; cat. 40588-V08B) and reconstituted in DPBS. OC43 subunit proteins were purified in 227 our laboratory as previously described ${ }^{18}$. Briefly, mammalian expression plasmids encoding the 228 S1 (amino acids 15-760) or S2 (amino acids 766-1305) domains of the OC43 spike protein were 229 cloned with an N-terminal OC43 S signal peptide, and a C-terminus encoding a Factor Xa cleavage 230 site, a trimerization domain from T4 fibritin (Foldon), a site-specific biotinylation sequence 231 (AviTag), and a hexa-histidine purification tag. 293F cells were transfected with S1 or S2 encoding 232 plasmids and proteins were purified from cell culture supernatant 6 days later with Ni-NTA resin 233 (Qiagen, Hilden, Germany). Proteins were concentrated and buffer exchanged into PBS with 234 Amicon centrifugal filters (Millipore, Burlington, MA) prior to quantification on a 235 spectrophotometer (NanoDrop, Thermo Fisher Scientific, Waltham, MA). 
medRxiv preprint doi: https://doi.org/10.1101/2021.09.30.21264363; this version posted October 1, 2021. The copyright holder for this preprint (which was not certified by peer review) is the author/funder, who has granted medRxiv a license to display the preprint in perpetuity. It is made available under a CC-BY-NC-ND 4.0 International license .

Antibodies reactive to SARS-CoV-2 and OC43 antigens were quantified by enzyme-linked immunosorbent assays (ELISA) as previously described ${ }^{18,54}$. Absorbed sera samples were also tested for the presence of influenza virus H1 HA antibodies. In brief, ELISA plates (Thermo Fisher Scientific, Waltham, MA: cat. 14-245-153) were coated overnight at $4^{\circ} \mathrm{C}$ with either $2 \mu \mathrm{g} / \mathrm{mL}$ SARS-CoV-2 or influenza HA antigens, $1.5 \mu \mathrm{g} / \mathrm{mL}$ OC43 antigens, or Dulbecco's phosphate

243 buffered saline (DPBS) to control for background antibody binding. Sera was heat-inactivated in 244 a $56^{\circ} \mathrm{C}$ water bath for 1 hour prior to serial dilutions starting at 1:50 in dilution buffer. ELISA 245 plates were blocked for 1 hour before $50 \mu \mathrm{L}$ of diluted sera was added and plates were incubated 246 for 2 hours on an orbital shaker. ELISA plates were washed 3 times with 1x PBS supplemented 247 with 2\% Tween (PBS-T) before the addition of goat anti-human IgG conjugated to horseradish 248 peroxidase secondary antibody at a 1:5000 dilution (Jackson ImmunoResearch Laboratories, West 249 Grove, PA: cat. 109-036-098). ELISA plates were developed with TMB substrate, and the 250 reactions were stopped after 5 minutes by the addition of $250 \mathrm{mM}$ hydrochloric acid prior to 251 reading on a SpectraMax 190 microplate reader (Molecular Devices, San Jose, CA). Serum 252 antibody titers were obtained from a standard curve of either serially diluted monoclonal antibody 253 (CR3022 for SARS-CoV-2 or CR9114 for influenza virus HA starting at $0.5 \mu \mathrm{g} / \mathrm{mL}$ ) or serially 254 diluted pooled serum (for OC43 ELISAs). Standard curves were included on every plate to control 255 for plate-to-plate variation. Antibody titers for each sample were measured in at least two technical 256 replicates performed on separate days.

\section{Carboxyl magnetic bead absorptions}

SARS-CoV-2 FL-S or OC43 FL-S antigens were coupled to carboxyl magnetic beads (RayBiotech, Peachtree Corners, GA; cat. 801-114-2) at a concentration of $35 \mu \mathrm{g}$ antigen/100 $\mu \mathrm{L}$ magnetic beads. Mock beads were prepared by the addition of DPBS in place of antigen. Briefly, $175 \mu \mathrm{g}$ of diluted antigen or PBS (for mock) was added to $500 \mu \mathrm{L}$ of magnetic beads and the mixture was incubated for 2 hours at $4^{\circ} \mathrm{C}$ with constant mixing. The unbound fractions were removed using a magnetic stand and conjugated beads were quenched by the addition of $300 \mu \mathrm{L}$

$26550 \mathrm{mM}$ Tris, $\mathrm{pH} 7.4$ prior to a 15-minute incubation at room temperature with constant mixing. 266 Quenching buffer was removed using a magnetic stand and the conjugated beads were washed 4 times with $300 \mu \mathrm{L}$ wash buffer (DPBS supplemented with 0.1\% BSA and 0.05\% Tween-20). After 
medRxiv preprint doi: https://doi.org/10.1101/2021.09.30.21264363; this version posted October 1, 2021. The copyright holder for this preprint (which was not certified by peer review) is the author/funder, who has granted medRxiv a license to display the preprint in perpetuity.

It is made available under a CC-BY-NC-ND 4.0 International license .

268 the final wash, beads were resuspended in $300 \mu \mathrm{L}$ wash buffer and were stored at $4^{\circ} \mathrm{C}$ prior to use

269 in serum absorption assays.

270 Sera samples were absorbed with beads coupled to SARS-CoV-2 FL-S, OC43 FL-S, and

271 mock beads. Sera samples were diluted in PBS to a final dilution of 1:25. Next, $20 \mu \mathrm{L}$ of antigen

272 coupled-magnetic beads or mock-treated beads were added to $100 \mu \mathrm{L}$ of diluted sera and the

273 mixtures were incubated for 1 hour at room temperature on a plate mixer at 800rpm. Fractions

274 containing the unabsorbed antibodies were removed using a 96-well plate magnetic stand.

275 Unabsorbed fractions were diluted in buffer (DPBS supplemented with 1\% milk and 0.1\% Tween-

276 20) prior to running in ELISA.

277

278 QUANTIFICATION AND STATISTICAL ANALYSIS

279 Statistical analyses were performed using Prism version 8 (GraphPad Software, San Diego CA).

280 Reciprocal serum dilution antibody titers were $\log 2$ transformed for statistical analysis. ELISA

281 antibody titers below the limit of detection (LOD) were set to a reciprocal titer equal to half the

282 LOD. Log2 transformed antibody titers were compared with paired and unpaired t-tests, and one-

283 way ANOVAs with Tukey's multiple comparisons. Statistical significance was defined as a p-

284 value $<0.05$.

285

286 DECLARATION OF INTERESTS

287 E.J.W. has consulting agreements with and/or is on the scientific advisory board for Merck,

288 Elstar, Janssen, Related Sciences, Synthekine and Surface Oncology. E.J.W. is a founder of

289 Surface Oncology and Arsenal Biosciences. E.J.W. is an inventor on a patent (U.S. patent

290 number 10,370,446) submitted by Emory University that covers the use of PD-1 blockade to

291 treat infections and cancer. S.E.H. has received consultancy fee from Sanofi Pasteur, Lumen,

292 Novavax, and Merck for work unrelated to this report. 
medRxiv preprint doi: https://doi.org/10.1101/2021.09.30.21264363; this version posted October 1, 2021. The copyright holder for this preprint (which was not certified by peer review) is the author/funder, who has granted medRxiv a license to display the preprint in perpetuity.

It is made available under a CC-BY-NC-ND 4.0 International license.

\section{ACKNOWLEDGEMENTS}

294 This project has been funded in part with Federal funds from the National Institute of Allergy

295 and Infectious Diseases, National Institutes of Health, Department of Health and Human

296 Services, under Contract No. 75N93021C00015. This work was supported in part by institutional

297 funds from the University of Pennsylvania and NIH U19AI082630 (S.E.H. and E.J.W.). E.M.A.

298 was supported by the NIH Training in Virology T32 Program (T32-AI-007324). We thank J.

299 Lurie, J. Embiid, J. Harris, and D. Blitzer for philanthropic support. We thank all members of the

300 Penn COVID-19 Sample Processing Unit. We would like to thank David Anderson for assistance

301 with the graphical abstract. The contents of this publication are solely the responsibility of the

302 authors and do not necessarily represent the official views of the NIH.

303

304

\section{AUTHOR CONTRIBUTIONS}

305 Serological Assays, E.M.A., T.E., E.C.G, and M.J.B.,

306 Data Analyses, E.M.A.

307 Cohort Studies and Sample Processing, S.G., R.R.G, M.M.P., S.A.A., D.M., D.D., D.F., A.B.,

308 J.W., J.M., S.D., the UPenn COVID Processing Unit, and A.R.G.

309 Manuscript Writing, E.M.A., and S.E.H.;

310 Supervision, I.F., D.J.R, E.J.W., and S.E.H.;

311 Funding Acquisition, I.F., D.J.R, E.J.W., and S.E.H.

\section{FIGURE LEGENDS}

\section{Figure 1.}

314 Specificity of SARS-CoV-2 antibodies induced after SARS-CoV-2 infection versus

315 vaccination. ELISAs were completed to quantify levels of serum antibodies binding to the

316 SARS-CoV-2 full-length spike (FL-S) protein, the S1 domain (S1) of S, and the S2 domain (S2)

317 of S after SARS-CoV-2 infection (A) and mRNA vaccination (B). Paired t-tests of $\log 2$

318 transformed antibody titers $* * * * p<0.0001, * * * p<0.001, * * p<0.01, * p<0.05$. We calculated fold-

319 change in antibody titers before and after seroconversion and pre-/post- prime and boost doses of 
medRxiv preprint doi: https://doi.org/10.1101/2021.09.30.21264363; this version posted October 1, 2021. The copyright holder for this preprint (which was not certified by peer review) is the author/funder, who has granted medRxiv a license to display the preprint in perpetuity.

It is made available under a CC-BY-NC-ND 4.0 International license .

320 a SARS-CoV-2 mRNA vaccine (C-E). One way ANOVA of antibody fold change

$321 * * * * \mathrm{p}<0.0001, * * \mathrm{p}<0.01 * \mathrm{p}<0.05$. Horizontal lines indicate geometric mean and error bars

322 represent standard deviation.

323

324 Figure 2.

325 Antibodies to a related seasonal coronavirus are boosted upon SARS-CoV-2 infection and

326 after vaccination to a lesser extent. ELISAs were completed to quantify levels of serum

327 antibodies binding to the betacoronavirus, OC43 full-length spike (FL-S) protein, the S1 domain

328 (S1) of S, and the S2 domain (S2) of S after SARS-CoV-2 infection (A) and mRNA vaccination

329 (B). Paired t-tests of $\log 2$ transformed antibody titers $* * * * \mathrm{p}<0.0001, * * * \mathrm{p}<0.001, * * \mathrm{p}<0.01$,

$330 * \mathrm{p}<0.05$. We calculated fold-change in antibody titers before and after seroconversion and pre-

331 /post- prime and boost doses of a SARS-CoV-2 mRNA vaccine (C-E). One way ANOVA of

332 antibody fold change $* * * * p<0.0001$ and $* * * p=0.0001$. Horizontal lines indicate geometric

333 mean and error bars represent standard deviation.

335 Figure 3.

336 Seasonal coronavirus spike antibodies boosted by SARS-CoV-2 infection do not bind well

337 to SARS-CoV-2 spike. Sera samples from 10 SARS-CoV-2 infected health care workers (A-C)

338 and 10 SARS-CoV-2 mRNA vaccinated participants (D-F) were absorbed with SARS-CoV-2

339 full length (FL) S-coupled beads, OC43 Full length (FL) S-coupled beads, or mock treated beads

340 prior to antibody quantification by ELISA. We determined reciprocal antibody titers in samples

341 before and after infection and pre-/post- the first dose of an mRNA vaccine for SARS-CoV-2

342 FL-S (A,D), OC43 FL-S (B,E), and an unrelated antigen, influenza hemagglutinin H1 (C, F).

343 Paired t-tests of $\log 2$ transformed antibody titers $* * * * \mathrm{p}<0.0001, * * * \mathrm{p}<0.001, * * \mathrm{p}<0.01$. 
medRxiv preprint doi: https://doi.org/10.1101/2021.09.30.21264363; this version posted October 1, 2021. The copyright holder for this preprint (which was not certified by peer review) is the author/funder, who has granted medRxiv a license to display the preprint in perpetuity.

\section{REFERENCES}

1 Carvalho, T., Krammer, F. \& Iwasaki, A. The first 12 months of COVID-19: a timeline of immunological insights. Nat Rev Immunol 21, 245-256, doi:10.1038/s41577-021-00522-1 (2021).

2 Zhou, P. et al. A pneumonia outbreak associated with a new coronavirus of probable bat origin. Nature 579, 270-273, doi:10.1038/s41586-020-2012-7 (2020).

3 Excler, J. L., Saville, M., Berkley, S. \& Kim, J. H. Vaccine development for emerging infectious diseases. Nat Med 27, 591-600, doi:10.1038/s41591-021-01301-0 (2021).

4 Gebre, M. S. et al. Novel approaches for vaccine development. Cell 184, 1589-1603, doi:10.1016/j.cell.2021.02.030 (2021).

5 Golob, J. L., Lugogo, N., Lauring, A. S. \& Lok, A. S. SARS-CoV-2 vaccines: a triumph of science and collaboration. JCI Insight, doi:10.1172/jci.insight. 149187 (2021).

6 Topol, E. J. Messenger RNA vaccines against SARS-CoV-2. Cell 184, 1401, doi:10.1016/j.cell.2020.12.039 (2021).

7 Baden, L. R. et al. Efficacy and Safety of the mRNA-1273 SARS-CoV-2 Vaccine. $N$ Engl $J$ Med 384, 403-416, doi:10.1056/NEJMoa2035389 (2021).

8 Polack, F. P. et al. Safety and Efficacy of the BNT162b2 mRNA Covid-19 Vaccine. $N$ Engl J Med 383, 2603-2615, doi:10.1056/NEJMoa2034577 (2020).

9 Collier, D. A. et al. Sensitivity of SARS-CoV-2 B.1.1.7 to mRNA vaccine-elicited antibodies. Nature 593, 136-141, doi:10.1038/s41586-021-03412-7 (2021).

10 Doria-Rose, N. et al. Antibody Persistence through 6 Months after the Second Dose of mRNA-1273 Vaccine for Covid-19. $N$ Engl $J$ Med 384, 2259-2261, doi:10.1056/NEJMc2103916 (2021).

11 Liu, Y. et al. Neutralizing Activity of BNT162b2-Elicited Serum. N Engl J Med 384, 14661468, doi:10.1056/NEJMc2102017 (2021).

12 Wang, Z. et al. mRNA vaccine-elicited antibodies to SARS-CoV-2 and circulating variants. Nature 592, 616-622, doi:10.1038/s41586-021-03324-6 (2021).

13 Widge, A. T. et al. Durability of Responses after SARS-CoV-2 mRNA-1273 Vaccination. $N$ Engl J Med 384, 80-82, doi:10.1056/NEJMc2032195 (2021).

$14 \mathrm{Wu}, \mathrm{K}$. et al. Serum Neutralizing Activity Elicited by mRNA-1273 Vaccine. $N$ Engl J Med 384, 1468-1470, doi:10.1056/NEJMc2102179 (2021).

15 Wang, Z. et al. Naturally enhanced neutralizing breadth against SARS-CoV-2 one year after infection. Nature 595, 426-431, doi:10.1038/s41586-021-03696-9 (2021).

16 Gouma, S. et al. Health care worker sero-monitoring reveals complex relationships between common coronavirus antibodies and COVID-19 symptom duration. JCI Insight, doi:10.1172/jci.insight.150449 (2021).

17 Sagar, M. et al. Recent endemic coronavirus infection is associated with less-severe COVID-19. J Clin Invest 131, doi:10.1172/JCI143380 (2021).

18 Anderson, E. M. et al. Seasonal human coronavirus antibodies are boosted upon SARSCoV-2 infection but not associated with protection. Cell 184, 1858-1864 e1810, doi:10.1016/j.cell.2021.02.010 (2021).

19 Dijkman, R. et al. The dominance of human coronavirus OC43 and NL63 infections in infants. J Clin Virol 53, 135-139, doi:10.1016/j.jcv.2011.11.011 (2012).

20 Dyrdak, R., Hodcroft, E. B., Wahlund, M., Neher, R. A. \& Albert, J. Interactions between seasonal human coronaviruses and implications for the SARS-CoV-2 pandemic: A 
medRxiv preprint doi: https://doi.org/10.1101/2021.09.30.21264363; this version posted October 1, 2021. The copyright holder for this preprint (which was not certified by peer review) is the author/funder, who has granted medRxiv a license to display the preprint in perpetuity. It is made available under a CC-BY-NC-ND 4.0 International license .

retrospective study in Stockholm, Sweden, 2009-2020. J Clin Virol 136, 104754, doi:10.1016/j.jcv.2021.104754 (2021).

21 Gaunt, E. R., Hardie, A., Claas, E. C., Simmonds, P. \& Templeton, K. E. Epidemiology and clinical presentations of the four human coronaviruses 229E, HKU1, NL63, and OC43 detected over 3 years using a novel multiplex real-time PCR method. J Clin Microbiol 48, 2940-2947, doi:10.1128/JCM.00636-10 (2010).

22 Huang, A. T. et al. A systematic review of antibody mediated immunity to coronaviruses: kinetics, correlates of protection, and association with severity. Nat Commun 11, 4704, doi:10.1038/s41467-020-18450-4 (2020).

23 Killerby, M. E. et al. Human coronavirus circulation in the United States 2014-2017. J Clin Virol 101, 52-56, doi:10.1016/j.jcv.2018.01.019 (2018).

24 Edridge, A. W. D. et al. Seasonal coronavirus protective immunity is short-lasting. Nat Med 26, 1691-1693, doi:10.1038/s41591-020-1083-1 (2020).

25 Eguia, R. T. et al. A human coronavirus evolves antigenically to escape antibody immunity. PLoS Pathog 17, e1009453, doi:10.1371/journal.ppat.1009453 (2021).

26 Kistler, K. E. \& Bedford, T. Evidence for adaptive evolution in the receptor-binding domain of seasonal coronaviruses OC43 and 229e. Elife 10, doi:10.7554/eLife.64509 (2021).

27 Jaimes, J. A., Andre, N. M., Chappie, J. S., Millet, J. K. \& Whittaker, G. R. Phylogenetic Analysis and Structural Modeling of SARS-CoV-2 Spike Protein Reveals an Evolutionary Distinct and Proteolytically Sensitive Activation Loop. J Mol Biol 432, 3309-3325, doi:10.1016/j.jmb.2020.04.009 (2020).

28 Okba, N. M. A. et al. Severe Acute Respiratory Syndrome Coronavirus 2-Specific Antibody Responses in Coronavirus Disease Patients. Emerg Infect Dis 26, 1478-1488, doi:10.3201/eid2607.200841 (2020).

29 Andersen, K. G., Rambaut, A., Lipkin, W. I., Holmes, E. C. \& Garry, R. F. The proximal origin of SARS-CoV-2. Nat Med 26, 450-452, doi:10.1038/s41591-020-0820-9 (2020).

30 Boni, M. F. et al. Evolutionary origins of the SARS-CoV-2 sarbecovirus lineage responsible for the COVID-19 pandemic. Nat Microbiol 5, 1408-1417, doi:10.1038/s41564-020-0771-4 (2020).

$31 \mathrm{Ng}, \mathrm{K}$. W. et al. Preexisting and de novo humoral immunity to SARS-CoV-2 in humans. Science 370, 1339-1343, doi:10.1126/science.abe1107 (2020).

32 Song, G. et al. Cross-reactive serum and memory B-cell responses to spike protein in SARS-CoV-2 and endemic coronavirus infection. Nat Commun 12, 2938, doi:10.1038/s41467-021-23074-3 (2021).

33 Nguyen-Contant, P. et al. S Protein-Reactive IgG and Memory B Cell Production after Human SARS-CoV-2 Infection Includes Broad Reactivity to the S2 Subunit. mBio 11, doi:10.1128/mBio.01991-20 (2020).

34 Jackson, L. A. et al. An mRNA Vaccine against SARS-CoV-2 - Preliminary Report. $N$ Engl J Med 383, 1920-1931, doi:10.1056/NEJMoa2022483 (2020).

35 Roltgen, K. et al. mRNA vaccination compared to infection elicits an IgG-predominant response with greater SARS-CoV-2 specificity and similar decrease in variant spike recognition. medRxiv, doi:10.1101/2021.04.05.21254952 (2021).

36 Amanat, F. et al. SARS-CoV-2 mRNA vaccination induces functionally diverse antibodies to NTD, RBD, and S2. Cell 184, 3936-3948 e3910, doi:10.1016/j.cell.2021.06.005 (2021). 
medRxiv preprint doi: https://doi.org/10.1101/2021.09.30.21264363; this version posted October 1, 2021. The copyright holder for this preprint (which was not certified by peer review) is the author/funder, who has granted medRxiv a license to display the preprint in perpetuity. It is made available under a CC-BY-NC-ND 4.0 International license .

37 McNaughton, A. L. et al. Fatal COVID-19 outcomes are associated with an antibody response targeting epitopes shared with endemic coronaviruses. medRxiv, 2021.2005.2004.21256571, doi:10.1101/2021.05.04.21256571 (2021).

38 Francis, T. On the Doctrine of Original Antigenic Sin. Proceedings of the American Philosophical Society 104, 572-578 (1960).

39 Arevalo, C. P. et al. Original antigenic sin priming of influenza virus hemagglutinin stalk antibodies. Proc Natl Acad Sci U S A 117, 17221-17227, doi:10.1073/pnas.1920321117 (2020).

40 Goel, R. R. et al. Distinct antibody and memory B cell responses in SARS-CoV-2 naive and recovered individuals following mRNA vaccination. Sci Immunol 6, doi:10.1126/sciimmunol.abi6950 (2021).

41 Lombardi, A. et al. Mini Review Immunological Consequences of Immunization With COVID-19 mRNA Vaccines: Preliminary Results. Front Immunol 12, 657711, doi:10.3389/fimmu.2021.657711 (2021).

42 Barnes, C. O. et al. Structures of Human Antibodies Bound to SARS-CoV-2 Spike Reveal Common Epitopes and Recurrent Features of Antibodies. Cell 182, 828-842 e816, doi:10.1016/j.cell.2020.06.025 (2020).

43 Letko, M., Marzi, A. \& Munster, V. Functional assessment of cell entry and receptor usage for SARS-CoV-2 and other lineage B betacoronaviruses. Nat Microbiol 5, 562-569, doi:10.1038/s41564-020-0688-y (2020).

44 Walls, A. C. et al. Structure, Function, and Antigenicity of the SARS-CoV-2 Spike Glycoprotein. Cell 181, 281-292 e286, doi:10.1016/j.cell.2020.02.058 (2020).

45 Wrapp, D. et al. Cryo-EM structure of the 2019-nCoV spike in the prefusion conformation. Science 367, 1260-1263, doi:10.1126/science.abb2507 (2020).

46 Greaney, A. J. et al. Antibodies elicited by mRNA-1273 vaccination bind more broadly to the receptor binding domain than do those from SARS-CoV-2 infection. Sci Transl Med 13, doi:10.1126/scitranslmed.abi9915 (2021).

47 Starr, T. N. et al. SARS-CoV-2 RBD antibodies that maximize breadth and resistance to escape. Nature, doi:10.1038/s41586-021-03807-6 (2021).

48 Stamatatos, L. et al. mRNA vaccination boosts cross-variant neutralizing antibodies elicited by SARS-CoV-2 infection. Science, doi:10.1126/science.abg9175 (2021).

49 Planas, D. et al. Reduced sensitivity of SARS-CoV-2 variant Delta to antibody neutralization. Nature, doi:10.1038/s41586-021-03777-9 (2021).

50 Turner, J. S. et al. SARS-CoV-2 mRNA vaccines induce persistent human germinal centre responses. Nature 596, 109-113, doi:10.1038/s41586-021-03738-2 (2021).

51 Brewer, R. C., Ramadoss, N. S., Lahey, L. J., Robinson, W. H. \& Lanz, T. V. BNT162b2 Vaccine Induces Divergent B cell responses to SARS-CoV-2 S1 and S2. medRxiv, 2021.2007.2020.21260822, doi:10.1101/2021.07.20.21260822 (2021).

52 Cobey, S. \& Hensley, S. E. Immune history and influenza virus susceptibility. Curr Opin Virol 22, 105-111, doi:10.1016/j.coviro.2016.12.004 (2017).

53 Amanat, F. et al. A serological assay to detect SARS-CoV-2 seroconversion in humans. Nat Med, doi:10.1038/s41591-020-0913-5 (2020).

54 Flannery, D. D. et al. SARS-CoV-2 seroprevalence among parturient women in Philadelphia. Sci Immunol 5, doi:10.1126/sciimmunol.abd5709 (2020). 


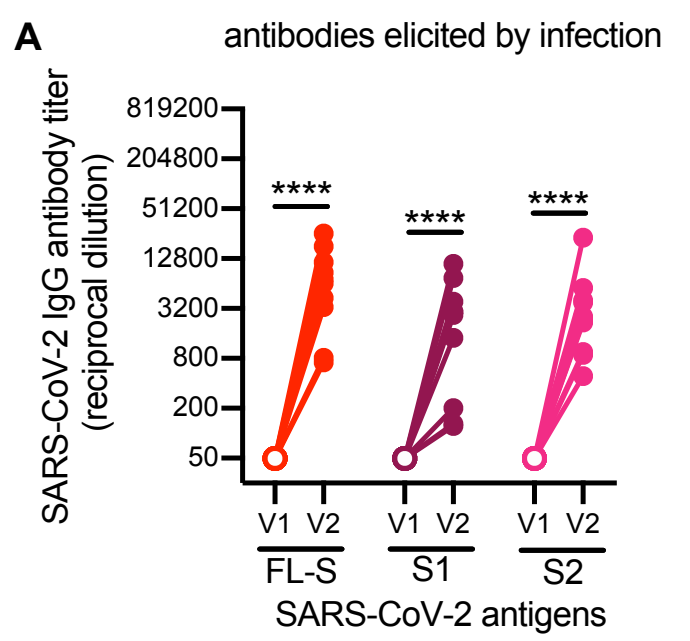

A antibodies elicited by infection

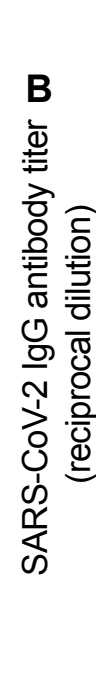

antibodies elicited by mRNA vaccination

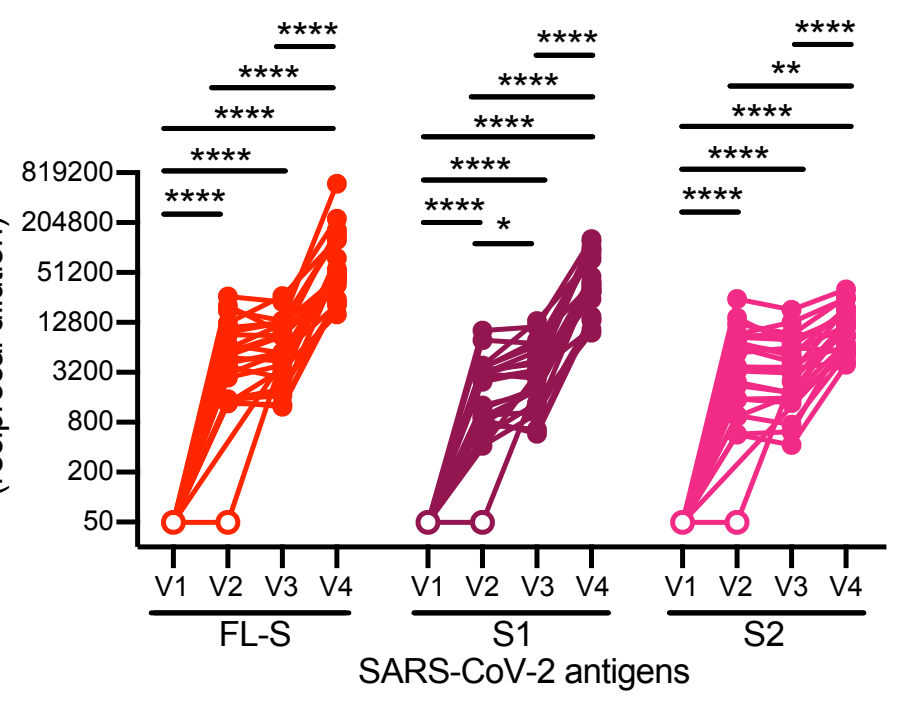

C

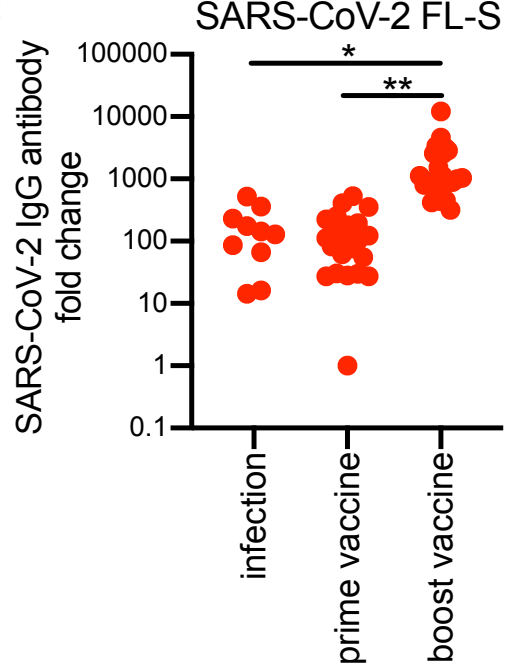

SARS-CoV-2 S1

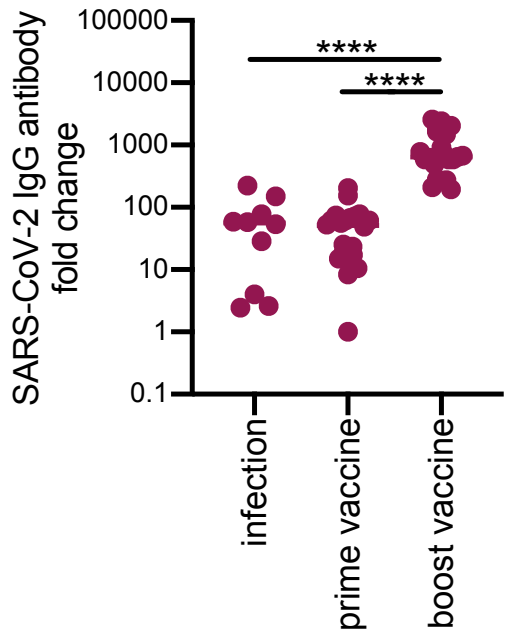

SARS-CoV-2 S2

E

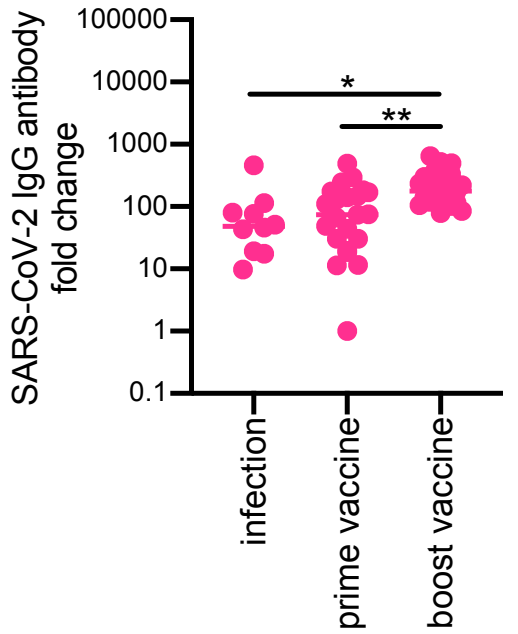


Anderson et al. 2021 Figure 2

A antibodies elicited by infection B

antibodies elicited by mRNA vaccination

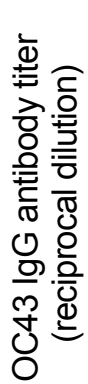
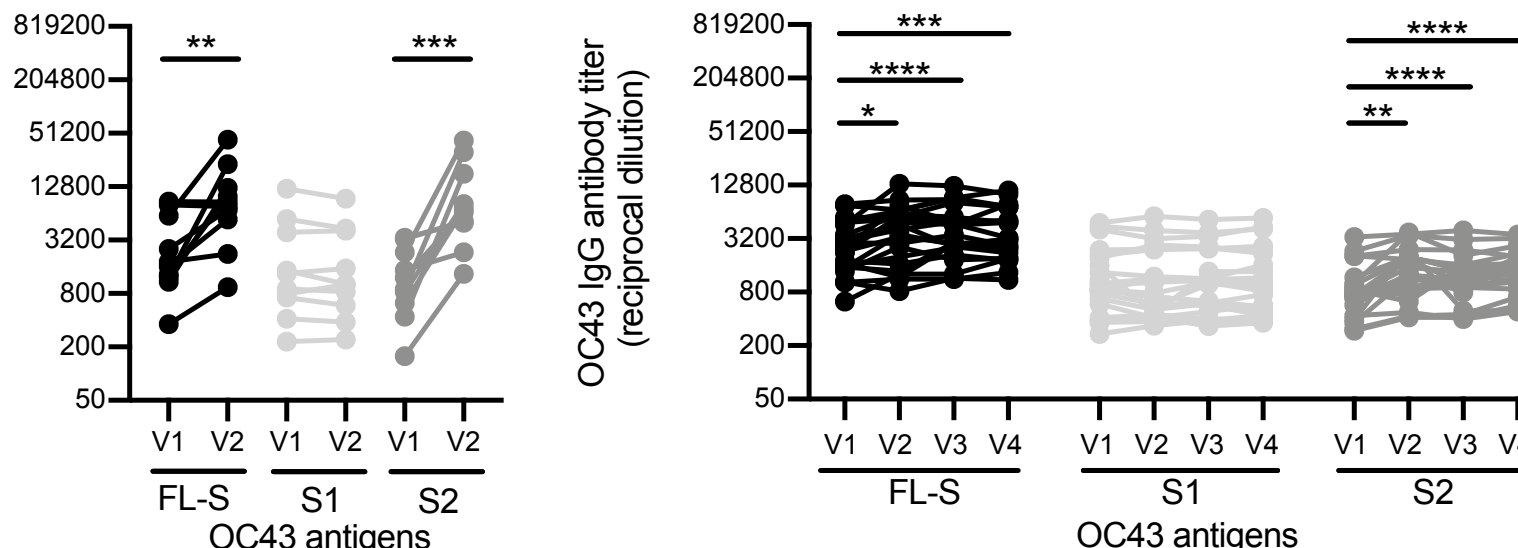

OC43 antigens
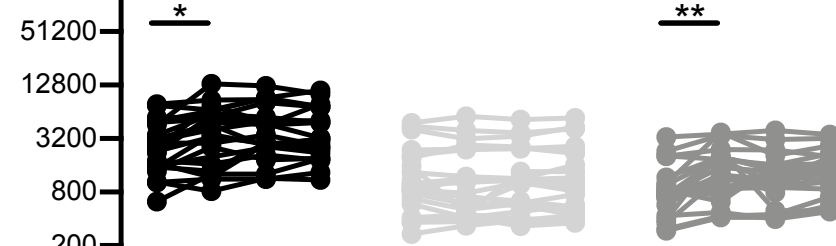

C

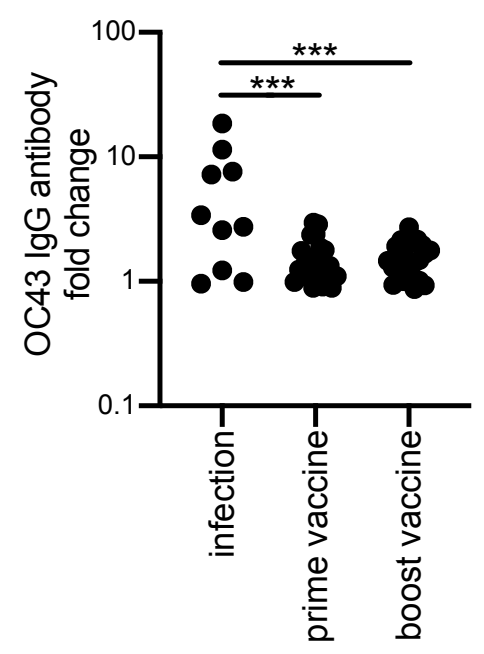

D

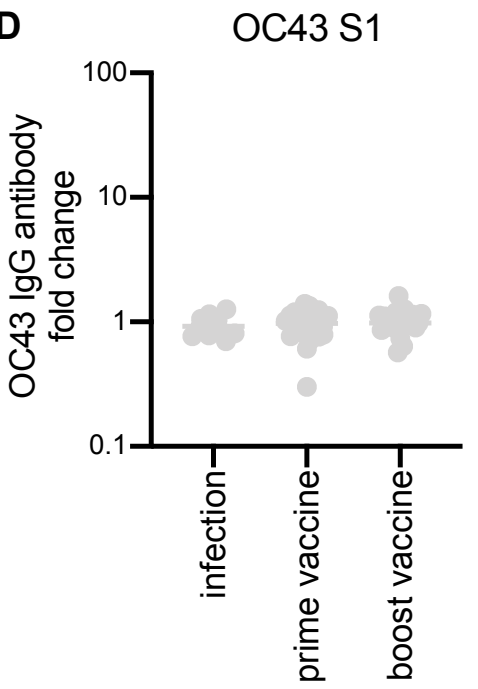

E

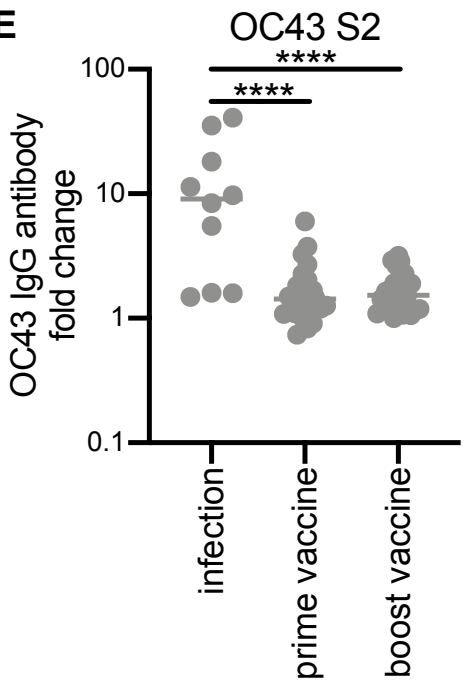




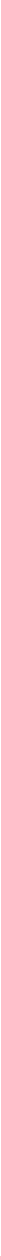


medRxiv preprint doi: https://doi.org/10.1101/2021.09.30.21264363; this version posted October 1, 2021. The copyright holder for this preprint (which was not certified by peer review) is the author/funder, who has granted medRxiv a license to display the preprint in perpetuity.

$$
\text { It is made available under a CC-BY-NC-ND } 4.0 \text { International license. }
$$

Supplemental Table 1

\begin{tabular}{|l|l|l|l|}
\hline & Infection & Vaccination & p-value \\
\hline Total $(\mathrm{N})$ & 10 & 23 & \\
\hline Median Age in years [min-max] & $35[25-49]$ & $38[23-67]$ & 0.8735 \\
\hline Number of Female [\%] & $8[80 \%]$ & $15[65 \%]$ & 0.6822 \\
\hline
\end{tabular}

